\title{
A ATUAÇÃO POLÍTICA DO JUDICIÁRIO: UMA PERSPECTIVA A PARTIR DA INCONSTITUCIONALIDADE DA LEI COMPLEMENTAR N¹00 DO ESTADO DE MINAS GERAIS E DA TESE JURÍDICA FIXADA NO RE 705.140/RS
}

\author{
Luís Carlos Balbino Gambogi ${ }^{1}$ \\ Danúbia Patrícia de Paiva ${ }^{2}$
}

\section{RESUMO}

A lei Complementar no 100/2007, que permitiu a alguns servidores do Estado de Minas Gerais ocuparem cargo efetivo sem concurso público, em 2014, foi reconhecida inconstitucional pelo Supremo Tribunal Federal.

Após, surgiram inúmeras ações judiciais com o intuito de ver reconhecidos direitos sociais destes agentes, o que permite inferir que ainda prevalece a insegurança jurídica em relação a estes trabalhadores.

Este estudo visa verificar uma interpretação coerente com os direitos fundamentais constitucionalmente assegurados, a partir do RE 705.140/RS, considerando ainda o papel político contemporâneo do Judiciário, a fim de contribuir para a solução dos conflitos.

Palavras-chave: Estado Democrático de Direito; Declaração de Inconstitucionalidade; Atuação Política do Judiciário; Servidor Público; Lei Complementar 100.

\section{THE POLITICAL ACTION OF THE JUDICIARY: A PERSPECTIVE FROM THE UNCONSTITUTIONALITY OF COMPLEMENTARY LAW 100 OF THE STATE OF MINAS GERAIS AND THE LEGAL THOUGHT FIXED IN RE 705.140 / RS.}

\begin{abstract}
Complementary Law 100/2007 guaranteed the employees of the State of Minas Gerais to hold an effective position without public tender. In 2014, it was recognized unconstitutional by the Federal Supreme Court.

Afterwards, numerous legal actions have arisen to recognize the social rights of these agents, which leads to the conclusion that legal insecurity prevails in relation to them.

This study aims to find, a coherent interpretation of the fundamental rights constitutionally assured, based on RE 705.140 / RS, considering also the contemporary political role of the Judiciary, in order to contribute to the solution of conflicts.
\end{abstract}

Keywords: Democratic state; Declaration of Unconstitutionality; Political action of the Judiciary; Public Server; Complementary Law 100.

\footnotetext{
${ }^{1}$ Possui graduação em Direito pela Pontifícia Universidade Católica de Minas Gerais (1979), mestrado em Direito pela Universidade Federal de Minas Gerais (1999) e doutorado em Filosofia do Direito pela Universidade Federal de Minas Gerais (2004). Já exerceu várias funções no Poder executivo mineiro, além de ter sido Deputado estadual constituinte. Atualmente é professor titular da Universidade Fundação Mineira de Educação e Cultura - FUMEC e Desembargador da $5^{\mathrm{a}}$ Câmara Cível do Tribunal de Justiça de Minas Gerais, provendo a vaga destinada ao Advogado (art. 94 da Constituição da República).

Doutoranda em Direito Processual Civil pela Puc Minas, mestre em Direito pela Faculdade de Ciências Humanas, Sociais e da Saúde $(\mathrm{FCH})$ da Universidade Fumec; possui Pós-graduação Lato Sensu em Direito Processual Civil pela Uniderp (2010); é graduada em Direito pela Universidade Federal de Minas Gerais (2007) e em Gestão Pública e Direito Administrativo pelo Centro Universitário de Belo Horizonte-UNI (2004).
} 


\section{INTRODUÇÃO}

A lei Complementar $n^{\circ} 100 / 2007$, que entrou em vigor no dia 05/11/2007, permitiu que alguns servidores públicos do Estado de Minas Gerais ocupassem cargo efetivo sem a realização de concurso público. A medida foi considerada um "arranjo" do governo de Minas Gerais para beneficiar quase cem mil servidores, tendo sido reconhecida inconstitucional pelo Supremo Tribunal Federal no ano de 2014.

No presente estudo, será objeto de análise o artigo $7^{\circ}$ da referida Lei, que trata da concessão de titularidade de cargo público efetivo a profissional da área da educação, que detinham vínculo com a administração pública do Estado de Minas Gerais ${ }^{3}$.

Este agentes públicos foram chamados de "designados" e passaram, a partir da vigência da lei, a ser incluídos no Instituto de Previdência do Estado de Minas Gerais.

Após a declaração de inconstitucionalidade pelo Supremo Tribunal Federal, estes trabalhadores deixaram de pertencer ao Regime Próprio de Previdência, o que fez surgir inúmeras ações judiciais com o intuito de ver reconhecidos alguns direitos sociais destes agentes.

Convém registrar, por relevante, que há pessoas que confiaram na validade da Lei Complementar n. 100, e que acabaram sendo excluídas de um regime previdenciário que acreditavam pertencer, de forma repentina. Há outras que foram mantidas, em razão da modulação dos efeitos da decisão de inconstitucionalidade.

O principal ponto a ser discutido, contudo, é em relação aos servidores atingidos pela inconstitucionalidade da Lei número 100/2007 que tiveram os seus direitos a aposentadoria e a regime previdenciário alterados.

A pesquisa será desenvolvida com dados de natureza primária e secundária. Dentre as informações de natureza primária, destacam-se as normas presentes no Ordenamento Jurídico Brasileiro, como a Constituição da República. Dentre os dados de origem secundária, serão

\footnotetext{
${ }^{3} \mathrm{O}$ texto apresentava a seguinte redação: “Art. $7^{\circ}$ Em razão da natureza permanente da função para a qual foram admitidos, são titulares de cargo efetivo, nos termos do inciso I do art. $3^{\circ}$ da Lei Complementar $n^{\circ} 64$, de 2002, os servidores em exercício na data da publicação desta lei, nas seguintes situações:

I - a que se refere o art. $4^{\circ}$ da Lei $n^{\circ} 10.254$, de 1990, e não alcançados pelos arts. 105 e 106 do Ato das Disposições Constitucionais Transitórias da Constituição do Estado;

II - estabilizados nos termos do art. 19 do Ato das Disposições Constitucionais Transitórias da Constituição da República;

III - a que se refere o caput do art. 107 da Lei no 11.050, de 19 de janeiro de 1993;

IV - de que trata a alínea "a" do $\S 1^{\circ}$ do art. 10 da Lei n ${ }^{\circ} 10.254$, de 1990, admitidos até 16 de dezembro de 1998 , desde a data do ingresso;

V - de que trata a alínea "a" do $\S 1^{\circ}$ do art. 10 da Lei no 10.254 , de 1990 , admitidos após 16 de dezembro de 1998 e até 31 de dezembro de 2006, desde a data do ingresso." (MINAS GERAIS, 2007).
} 
analisadas as literaturas jurídicas em geral, artigos científicos publicados em periódicos classificados pela CAPES, livros e teses e dissertações de doutorado de mestrado, respectivamente.

Com o intuito de compreender a questão objeto de estudo, primeiramente será analisada a Lei Complementar número 100/2007, seu surgimento e os motivos que levaram à efetivação destes servidores.

Em seguida, será examinada a regra do concurso público, seus princípios e suas exceções, tópico relevante para analisar, posteriormente, a declaração de inconstitucionalidade da Lei Complementar 100/2007, bem como os principais argumentos que a nortearam.

Por fim, será dada atenção à modulação dos efeitos da referida decisão e ao problema da ausência de regras claras para reger esta categoria de servidores, o que permite, a princípio, a aplicação da tese jurídica fixada no RE 705.140/RS, com repercussão geral reconhecida, que firmou entendimento no sentido de que as contratações realizadas pela Administração, sem prévio concurso público, não geram quaisquer efeitos jurídicos válidos, a não ser o direito à percepção dos salários referentes ao período trabalhado e ao levantamento dos depósitos efetuados no Fundo de Garantia por Tempo de Serviço - FGTS (BRASIL, 2014).

Neste ponto, também será considerada a relevância contemporânea da atividade judicial, de forma geral, de considerável interferência nas relações sociais e políticas.

A expectativa é que este estudo seja útil à comunidade jurídica e à sociedade, a fim de contribuir para a solução do problema de cunho previdenciário e social destes trabalhadores, direitos estes que são devidos a todo trabalhador, previstos constitucionalmente no artigo $7^{\circ}$ da Constituição da República de 1988 (CR/88) (BRASIL, 1988).

\section{BREVES CONSIDERAÇÕES SOBRE O SURGIMENTO DA LEI COMPLEMENTAR No 100/2007}

Com o intuito de resolver um problema que persistia há mais de três décadas, o Estado de Minas Gerais criou a Lei Complementar $n^{\circ}$ 100, de 05 de novembro de 2007.

Referida lei tratou de diversos trabalhadores, em sua grande maioria, professores e serventes escolares, que conviviam com a incerteza em relação ao direito de aposentadoria, direito este que é devido a todo trabalhador, previsto constitucionalmente no artigo $7^{\circ}$ da Constituição da República de 1988 (BRASIL, 1988). 
A Lei Complementar $n^{\circ} 100$ foi criada para regularizar a situação previdenciária desses trabalhadores, que eram servidores não efetivos do Estado, mas exerciam cargos efetivos, sendo enquadrados como "função pública", chamados usualmente de "designados" ou "efetivados".

Esses trabalhadores exerciam cargos de professores, especialistas, serventes e auxiliares de educação e não tinham regulamentado o direito a benefício previdenciário pela administração pública estadual, e tampouco pelo Instituto Nacional do Seguro Social (INSS).

Com o advento da Lei Complementar $\mathrm{n}^{\circ} 100$, tais servidores passaram a ter seus direitos previdenciários reconhecidos, sob as mesmas condições dos trabalhadores com vinculação de natureza permanente, mas sem a estabilidade, direito exclusivo dos servidores aprovados em concurso público.

Por outro lado, alguns servidores, que não conseguiram ver reconhecido o direito à efetivação, ficaram vinculados ao Regime Geral de Previdência Social.

Portanto, nota-se que a intenção da Lei foi regularizar a situação Previdenciária destes servidores. Na prática, contudo, o que se observou foi à manutenção de outra situação irregular, uma vez que aqueles beneficiados pela Lei Complementar 100 estavam ocupando vaga "reservada" constitucionalmente a servidores concursados.

\section{A REgÊnCIA DA ADMINISTRAÇÃo PÚBLICA PELO CONCURSO PÚbLICO}

O concurso público no Brasil tem o intuito de selecionar candidatos qualificados para assumirem vagas em caráter efetivo. O objetivo é buscar as pessoas mais qualificadas, razão pela qual o concurso observa os princípios da igualdade e isonomia, a fim de selecionar candidatos aptos e competentes para os cargos.

José dos Santos Carvalho Filho define concurso público nos seguintes termos:

Concurso Público é o procedimento administrativo que tem por fim aferir as aptidões pessoais e selecionar os melhores candidatos ao provimento de cargos e funções públicas. Na aferição pessoal, o Estado verifica a capacidade intelectual, física e psíquica de interessados em ocupar funções públicas e no aspecto seletivo são escolhidos aqueles que ultrapassam as barreiras opostas no procedimento, obedecidas sempre à ordem de classificação. Cuida-se, na verdade, do mais idôneo meio de recrutamento de servidores públicos. (CARVALHO FILHO, 2014, p. 472). 
Segundo a Constituição da República de 1988, o concurso deve ser realizado com aplicação de provas ou de provas e títulos, podendo ter mais de uma etapa. Os concursos podem ainda ter validade de até dois anos, depois de publicada a sua aprovação, podendo ser prorrogada esta somente uma vez, por idêntico período de tempo (Art. 37, III, CR/88) (BRASIL, 1988).

A seguir, serão apresentados alguns princípios que norteiam os concursos públicos, os quais devem ser observados, sob pena de reconhecimento da nulidade destes.

\subsection{PRINCÍPIOS APLICÁVEIS À REGRA DO CONCURSO PÚBLICO}

O texto constitucional, em seu inciso XXI e nos $\S \S 5^{\circ}$ e $6^{\circ}$ do artigo 37 , descreve os princípios da Administração Pública, mencionando os princípios da legalidade, impessoalidade, moralidade, publicidade e eficiência (BRASIL, 1988). A seguir, será resumidamente tratado cada um, a partir dos principais conceitos doutrinários existentes.

O Princípio da Legalidade, nas palavras de Kildare Gonçalves Carvalho, subordina a Administração Pública à lei:

[...] visão positivista do direito, diferentemente do indivíduo, que é livre para agir, podendo fazer tudo o que a lei não proíbe a administração somente poderá fazer o que a lei manda ou permite. [...] O princípio da legalidade, é preciso lembrar, deve submeter-se, no Estado Democrático de Direito, ao exame da parametricidade constitucional, seja formal, seja material, buscando sua validade nos princípios constitucionais. A legalidade administrativa associa-se, em especial, ao princípio da razoabilidade, vale dizer, à adequação entre meios e fins, com a vedação de imposição de obrigações ou sanções em medida superior àquelas estritamente necessárias ao atendimento do interesse público. (CARVALHO, 2010, p. 1.092).

Já o Princípio da Impessoalidade revela que os atos da Administração Pública não são imputáveis a quem os pratica, mas a órgão ou entidade administrativa competente. A impessoalidade consiste, ainda, na vedação de tratamento discriminatório pelos agentes públicos (CARVALHO, 2010, p. 1.093).

A moralidade administrativa, por sua vez, deve ser interpretada no sentido de que o administrador deverá agir respeitando o ordenamento jurídico vigente, bem como os padrões de conduta eleitos pela comunidade.

A gestão da coisa pública deve-se orientar de conformidade com os padrões de conduta que a comunidade elegeu como relevantes num 
determinado momento histórico, para o aperfeiçoamento da vida em comum, sob o influxo de um poder central.

A moralidade surge para coibir as arbitrariedades e os excessos cometidos pelo Poder Público, na esfera da discricionariedade, submetendo-se a Administração à finalidade a que devia visar. A exigência do comportamento conforme à moralidade representa uma evolução do controle de desvio de finalidade ou de excesso de poder. (CARVALHO, 2010, p. 1.093-1.094).

Já o Princípio da Publicidade indica que os atos da Administração devem merecer a mais ampla divulgação possível. Segundo José dos Santos Carvalho Filho, tal característica constitui fundamento deste princípio, a propiciar o controle da legitimidade da conduta dos agentes administrativos:

É para observar esse princípio que os atos administrativos são publicados em órgãos de imprensa ou afixados em determinado local das repartições administrativas, ou, ainda, mais modernamente, divulgados por outros mecanismos integrantes da tecnologia da informação, como é o caso da Internet. O princípio da publicidade pode ser concretizado por alguns instrumentos jurídicos específicos, citando entre eles: o direito de petição, pelo qual os indivíduos podem dirigir-se aos órgãos administrativos para formular qualquer tipo de postulação (art. 5', XXXIV, “a”, CR); as certidões, que, expedidas por tais órgãos, registram a verdade de fatos administrativos, cuja publicidade permite aos administrados a defesa de seus direitos ou a esclarecimentos de certas situações (art. 50, XXXIV, "b", CR); e a ação administrativa ex officio de divulgação de informações de interesse público. (CARVALHO FILHO, 2014, p. 26).

Por fim, há o Princípio da Eficiência que foi introduzido pela Emenda Constitucional número 19/98, que visa desenvolver na Administração Pública a ideia de que suas atividades precisam extrair efeitos positivos ao administrado, sopesando a relação custo-benefício, buscando a excelência de recursos, dotando de maior eficácia possível as ações do Estado (CARVALHO, 2010, p. 1.096-1.097).

Todos estes princípios visam contribuir para que o concurso público atenda ao interesse público, visando à escolha do melhor candidato, a fim de impedir que os certames públicos sejam marcados por favorecimentos.

\subsection{EXCEÇÕES À REGRA DO CONCURSO PÚBLICO}

Após apresentados os principais princípios aplicáveis ao concurso público, serão a analisadas as exceções verificadas à regra do concurso público. 


\subsubsection{DOS CARGOS EM COMISSÃO E FUNÇÕES DE CONFIANÇA}

A Constituição, no art. 37, V, traz a previsão afeta às "funções de confiança" e aos cargos em comissão (BRASIL, 1988).

Para José dos Santos Carvalho Filho, a expressão "funções de confiança" foi utilizada, sem, na verdade, precisar o seu real sentido. Na prática, contudo, o que se verificou foi que a função pública melhor se identificou com o conceito de função gratificada, ou de confiança, que é reservada exclusivamente aos servidores ocupantes de cargo efetivo, ainda que sejam lotados em órgão diverso (CARVALHO FILHO, 2014, p. 615-617).

As funções de confiança, então, são aquelas oferecidas aos servidores efetivos.

Por outro lado, há a previsão constitucional afeta aos cargos em comissão, que podem ser ocupados por qualquer cidadão, independentemente se já existe relação deste com a Administração Pública, sendo tal categoria, portanto, excluída da regra do concurso público.

\subsubsection{DA CONTRATAÇÃO TEMPORÁRIA}

A categoria dos servidores públicos temporários trata-se de um agrupamento excepcional dentro da categoria geral dos servidores públicos.

A previsão desta categoria está contemplada no art. 37, IX, da CR/88, que admite a sua contratação por tempo determinado para atender à necessidade temporária de excepcional interesse público (BRASIL, 1988).

Nota-se que o texto constitucional demonstra o caráter de excepcionalidade de tais agentes. Entretanto, admitido o seu recrutamento na forma da lei, serão estes agentes considerados como integrantes da categoria geral dos servidores públicos. (CARVALHO FILHO, 2014, p. 602).

Aos servidores temporários, então, não há necessidade de realização de concurso público, pois, mesmo exercendo função pública, eles não detêm cargo ou emprego público.

Contudo, para este tipo de contratação é necessário, que seja observada a regra da excepcionalidade do interesse público:

[...] a excepcionalidade do interesse público que obriga ao recrutamento. Empregando o termo excepcional para caracterizar o interesse público do Estado, a Constituição deixou claro que situações administrativas comuns não podem ensejar o chamamento desses servidores. Portanto, pode dizer-se que a excepcionalidade do interesse público corresponde à excepcionalidade do próprio regime 
especial. Algumas vezes o Poder Público, tal como sucede com o pressuposto anterior e em regra com o mesmo desvio de poder, simula desconhecimento de que a excepcionalidade do interesse público é requisito inafastável. [...] Sensível a esse tipo de evidente abuso - no mínimo ofensivo ao princípio da moralidade administrativa - o STF julgou procedente ação direta e declarou a inconstitucionalidade de lei estadual que permitia o recrutamento de servidores pelo regime especial temporário, calcando-se em dois fundamentos: $\left(1^{\circ}\right)$ falta de especificação das atividades de excepcional interesse público; $\left(2^{\circ}\right)$ ausência de motivação quanto à real necessidade temporária das funções a serem exercidas. (CARVALHO FILHO, 2014, p. 610-611).

Há ainda outros pressupostos para a contratação apontados, que se referem à temporalidade da contratação e da função, pois a necessidade do serviço deve ser temporária (CARVALHO FILHO, 2014, p. 610-611).

Verificadas as principais situações relacionadas às regras do concurso público, bem como as situações de afastamento deste na Administração Pública brasileira, passa-se ao exame da Ação Direta de Inconstitucionalidade $n^{\circ} 4.876$ do STF, que analisou a Lei Complementar $n^{\circ} 100 / 2007$.

\section{A AÇÃO DIRETA DE INCONSTITUCIONALIDADE $\mathbf{N}^{\circ} 4.876$ DO STF - PRINCIPAIS ARGUMENTOS APRESENTADOS}

A Lei Complementar $\mathrm{n}^{0} 100 / 2007$, como já noticiado, foi reconhecida inconstitucional pelo STF na $\operatorname{ADIN~n}^{0}$ 4.876, sendo os efeitos da referida decisão tema de estudo do presente trabalho.

A seguir será analisada a declaração de inconstitucionalidade, bem como os principais argumentos apresentados nesta ação.

\subsection{ARGUMENTOS APRESENTADOS PELO PROCURADOR GERAL DA REPÚBLICA}

O Procurador Geral da República afirmou na petição inicial da ADIN n 4.876 que, embora se tenha noticiado que a Lei Complementar $n^{\circ} 100$ tem a finalidade de regularizar a situação previdenciária dos servidores, o seu intuito verdadeiro foi a aquisição de certificado de regularização previdenciária junto ao Ministério de Previdência Social (BRASIL, 2014).

Assim, defendeu que os dispositivos da referida lei, neste particular, violariam diretamente a $\mathrm{CR} / 88$, pois permitiram a entrada de servidores públicos sem prévia aprovação 
em concurso público, violando os princípios constitucionais, da isonomia, da impessoalidade e da moralidade administrativa, além da regra da obrigatoriedade do concurso público.

Afirmou, ainda, que existem apenas duas exceções permitidas constitucionalmente: as investiduras por livre nomeação e exoneração e a contratação temporária.

Por fim, requereu a concessão de medida cautelar, para que essa acarretasse a suspensão da eficácia do art. $7^{\circ}$ da Lei Complementar $n^{\circ} 100$ até o julgamento do mérito da ação. Requereu, também, que o pedido fosse julgado procedente, e que todo o art. $7^{\circ}$ da Lei Complementar, fosse declarado inconstitucional.

\subsection{ARGUMENTOS APRESENTADOS PELOS MINISTROS DO STF}

O STF, em sua maioria decidiu pela inconstitucionalidade da lei, visto que o Poder Legislativo Estadual, ao estender direitos inerentes ao provimento de cargo efetivo aos ocupantes de função pública, extrapolou seus limites de regulamentação, violando disposição expressa da Carta Maior que exige, para a investidura em cargos públicos, aprovação prévia em concurso público. É o que decidiu o Supremo Tribunal Federal, no julgamento da Ação Direta de Inconstitucionalidade, em acórdão assim ementado:

Ação direta de inconstitucionalidade. Artigo $7^{\circ}$ da Lei Complementar $\mathrm{n}^{\mathrm{o}}$ 100/2007 do Estado de Minas Gerais. Norma que tornou titulares de cargos efetivos servidores que ingressaram na administração pública sem concurso público, englobando servidores admitidos antes e depois da Constituição de 1988. Ofensa ao art. 37, inciso II, da Constituição Federal, e ao art. 19 do Ato das Disposições Constitucionais Transitórias. Modulação dos efeitos. Procedência parcial. 1. Desde a Constituição de 1988, por força do seu art. 37, inciso II, a investidura em cargo ou emprego público depende da prévia aprovação em concurso público. As exceções a essa regra estão taxativamente previstas na Constituição. Tratando-se, no entanto, de cargo efetivo, a aprovação em concurso público se impõe. 2. O art. 19 do Atos das Disposições Constitucionais Transitórias tornou estáveis os servidores que estavam em exercício há pelo menos cinco anos na data da promulgação da Constituição de 1988. A estabilidade conferida por essa norma não implica a chamada efetividade, que depende de concurso público, nem com ela se confunde. Tal dispositivo é de observância obrigatória pelos estados. Precedentes: ADI $n^{\circ}$ 289/CE, Relator o Ministro Sepúlveda Pertence, Tribunal Pleno, DJ de 16/3/07; RE no 199.293/SP, Relator o Ministro Marco Aurélio, Tribunal Pleno, DJ de 6/8/04; ADI n ${ }^{\circ}$ 243/RN-MC, Relator o Ministro Maurício Corrêa, Tribunal Pleno, DJ de 24/8/01; RE $n^{\circ}$ 167635/PA, Relator o Ministro Maurício Corrêa, Segunda Turma, DJ 
de 7/2/97. 3. Com exceção do inciso III (que faz referência a servidores submetidos a concurso público), os demais incisos do art. $7^{\circ}$ da Lei Complementar $n^{\circ} 100$, de 2007, do Estado de Minas Gerais tornaram titulares de cargo efetivo servidores que ingressaram na Administração Pública com evidente burla ao princípio do concurso público (art. 37, II, CF/88). 4. Modulação dos efeitos da declaração de inconstitucionalidade, nos termos do art. 27 da Lei $n^{\circ}$ 9.868/99, para, i) em relação aos cargos para os quais não haja concurso público em andamento ou com prazo de validade em curso, dar efeitos prospectivos à decisão, de modo a somente produzir efeitos a partir de doze meses, contados da data da publicação da ata de julgamento, tempo hábil para a realização de concurso público, a nomeação e a posse de novos servidores, evitando-se, assim, prejuízo à prestação de serviços públicos essenciais à população; ii) quanto aos cargos para os quais exista concurso em andamento ou dentro do prazo de validade, a decisão deve surtir efeitos imediatamente. Ficam, ainda, ressalvados dos efeitos da decisão (a) aqueles que já estejam aposentados e aqueles servidores que, até a data de publicação da ata deste julgamento, tenham preenchido os requisitos para a aposentadoria, exclusivamente para efeitos de aposentadoria, o que não implica efetivação nos cargos ou convalidação da lei inconstitucional para esses servidores, uma vez que a sua permanência no cargo deve, necessariamente, observar os prazos de modulação acima; (b) os que foram nomeados em virtude de aprovação em concurso público, imprescindivelmente, no cargo para o qual foram aprovados; e (c) a estabilidade adquirida pelos servidores que cumpriram os requisitos previstos no art. 19 do ADCT da Constituição Federal. 5. Ação direta julgada parcialmente procedente. (BRASIL, 2014).

O Relator Ministro Dias Toffoli ressalvou em seu voto que, com exceção do inciso III, os demais incisos do art. $7^{\circ}$ da Lei Complementar $n^{\circ} 100$ significaram evidente burla ao princípio do concurso público (art. 37, II, CR/88). Contudo, consoante se extrai da própria ementa, a decisão sofreu modulações, que devem ser analisadas com afinco.

A lei 9.868/99 dispõe sobre o processo e julgamento da ação direta de inconstitucionalidade e da ação declaratória de constitucionalidade diante do Supremo Tribunal Federal.

O artigo 27 desta lei descreve em seu texto a possibilidade, mediante maioria de dois terços dos seus membros, de restringirem os efeitos de sua decisão, bem como que esta só tenha eficácia a partir de dado momento.

Art. 27. Ao declarar a inconstitucionalidade de lei ou ato normativo, e tendo em vista razões de segurança jurídica ou de excepcional interesse social, poderá o Supremo Tribunal Federal, por maioria de dois terços de seus membros, restringir os efeitos daquela declaração 
ou decidir que ela só tenha eficácia a partir de seu trânsito em julgado ou de outro momento que venha a ser fixado. (BRASIL, 1999).

Na ADI 4876, a modulação da Lei Complementar de número 100 se deu em relação aos cargos para os quais não havia concurso público em andamento ou com prazo de validade em curso, para dar efeitos prospectivos à decisão, de modo a somente produzir efeitos a partir de doze meses, contados da data da publicação da ata de julgamento, tempo hábil para a realização de concurso público, nomeação e posse de novos servidores, evitando-se, assim, prejuízo à prestação de serviços públicos essenciais à população.

Quanto aos cargos para os quais existia concurso em andamento ou dentro do prazo de validade, a decisão deveria surtir efeitos imediatamente, ficando todavia ressalvados dos efeitos da decisão aqueles que já estejam aposentados e aqueles servidores que, até a data de publicação da ata do julgamento, tenham preenchido os requisitos para a aposentadoria.

Para alguns servidores, então, a decisão significou não a permissão da efetivação destes, mas apenas a manutenção dos efeitos de aposentadoria no Regime Próprio dos Servidores Públicos do Estado de Minas Gerais.

Neste cenário, a modulação da decisão buscou defender a segurança jurídica e o excepcional interesse social dos trabalhadores, os chamados "designados", mas acabou representando situação de desigualdade entre servidores que se encontravam regidos por aquela lei.

Diante deste cenário, surgiram diversas ações judiciais a fim de serem reconhecidos direitos sociais destes agentes, excluídos do Regime Próprio de Previdência Social, sendo relevante analisar quais seriam estes direitos.

\section{OS DIREITOS SOCIAIS ASSEGURADOS AOS SERVIDORES PÚBLICOS EM GERAL E A TESE JURÍDICA FIXADA NO RE 705.140/RS}

Como já salientado, o STF reconheceu que é inconstitucional o artigo $7^{\circ}$ da Lei Complementar $n^{\circ}$ 100/2007 do Estado de Minas Gerais, norma que tornou titulares de cargos efetivos os servidores que ingressaram na administração pública sem concurso público.

Em outras palavras, reconheceu o STF que os servidores públicos efetivados pela Lei Complementar $\mathrm{n}^{\circ}$ 100/2007 não podem ser enquadrados como servidores ocupantes de cargo público, porque tal condição é privativa de agente público ocupante de cargo efetivo, aprovado em concurso público. 
Neste cenário, cabe esclarecer em qual regime jurídico se enquadram esses servidores indevidamente efetivados pela Lei Complementar $\mathrm{n}^{\circ}$ 100/2007, sendo, a priori, impossível excluí-los das hipóteses taxativamente previstas na Constituição, sob pena de se admitir, à revelia do ordenamento jurídico, uma nova categoria de servidor público, cujo vínculo administrativo seria "criado", em afronta direta ao ordenamento jurídico.

Assim, em se considerando o reconhecimento da inconstitucionalidade do artigo $7^{\circ}$ da Lei Complementar $n^{\circ}$ 100/2007, do Estado de Minas Gerais, ou se coloca esses servidores no "limbo jurídico" ou se reconhece que eles passaram a integrar o regime jurídico administrativo, próprio dos contratados temporariamente, nos termos do artigo 37, IX, da Constituição da República.

Tal entendimento é defendido neste artigo a partir de uma interpretação lógica da própria jurisprudência do Supremo Tribunal Federal e das regras afetas aos agentes públicos. Em se considerando que esses servidores não podem ser considerados efetivos ou comissionados, nem que são regidos pela CLT, a fim de serem identificados como empregados públicos, só podem ser enquadrados como servidores públicos temporários.

Os servidores públicos são os agentes que possuem vínculo com a Administração Pública direta, autárquica ou fundacional, e que recebem remuneração paga pelo erário.

Enquadram-se neste conceito três categorias de servidores: os servidores estatutários, cujo regime jurídico é estabelecido por lei; os empregados públicos, que são contratados pelo regime trabalhista, regido pela CLT, observada a condição do contratante (ente público); e os servidores temporários, os quais são contratados para atender a necessidade temporária de excepcional interesse público, exercendo função sem, contudo, se encontrarem vinculados a cargo ou emprego público.

Sobre o tema, é a lição de José dos Santos Carvalho Filho:

Essa classificação atende a dois critérios: a natureza do vínculo jurídico que liga o servidor ao Poder Público e a natureza dessas funções.

Servidores públicos estatutários são aqueles cuja relação jurídica de trabalho é disciplinada por diplomas legais específicos, denominados de estatutos. Nos estatutos estão inscritas todas as regras que incidem sobre a relação jurídica, razão por que nelas se enumeram os direitos e deveres dos servidores e do Estado.

A segunda categoria é a dos servidores públicos trabalhistas (ou celetistas), assim qualificados porque as regras disciplinadoras de sua relação de trabalho são as constantes da Consolidação das Leis do Trabalho. Seu regime básico, portanto, é o mesmo que se aplica à 
relação de emprego no campo privado, com as exceções, é lógico, pertinentes à posição especial de uma das partes - o Poder Público.

A última categoria é a dos servidores públicos temporários, os quais, na verdade, se configuram como um agrupamento excepcional dentro da categoria geral dos servidores públicos. A previsão dessa categoria especial de servidores está contemplada no art. 37, IX, da CF, que admite a sua contratação por tempo determinado para atender à necessidade temporária de excepcional interesse público. A própria leitura do texto constitucional demonstra o caráter de excepcionalidade de tais agentes. Entretanto, admitido o seu recrutamento na forma da lei, serão eles considerados como integrantes da categoria geral dos servidores públicos. (CARVALHO FILHO, 2014, p. 618/619).

Assim, diante do reconhecimento da inconstitucionalidade do vínculo jurídico que decorria de lei estadual Complementar no 100/2007, deve-se admitir que o vínculo destes servidores, durante o período em que prestaram serviços à Administração Pública, deve ser entendido como contemplado no art. 37, IX, da CR/88, que admite a contratação por tempo determinado para atender à necessidade temporária de excepcional interesse público.

A partir disso, é possível permitir a aplicação da tese apresentada no RE 705.140/RS, que determinou que as contratações ilegítimas não geram quaisquer efeitos jurídicos válidos, a não ser o direito à percepção dos salários referentes ao período trabalhado e, nos termos do art. 19-A da Lei 8.036/90, ao levantamento dos depósitos efetuados no Fundo de Garantia por Tempo de Serviço - FGTS. Referido acórdão foi assim ementado:

CONSTITUCIONAL E TRABALHO. CONTRATAÇÃO DE PESSOAL PELA ADMINISTRAÇÃO PÚBLICA SEM CONCURSO. NULIDADE. EFEITOS JURÍDICOS ADMISSÍVEIS EM RELAÇÃO A EMPREGADOS: PAGAMENTO DE SALDO SALARIAL E LEVANTAMENTO DE FGTS (RE 596.478 - REPERCUSSÃO GERAL). INEXIGIBILIDADE DE OUTRAS VERBAS, MESMO A TÍTULO INDENIZATÓRIO.

1. Conforme reiteradamente afirmado pelo Supremo Tribunal Federal, a Constituição de 1988 reprova severamente as contratações de pessoal pela Administração Pública sem a observância das normas referentes à indispensabilidade da prévia aprovação em concurso público, cominando a sua nulidade e impondo sanções à autoridade responsável $\left(\mathrm{CF}\right.$, art. $\left.37, \S 2^{\circ}\right)$. 2. No que se refere a empregados, essas contratações ilegítimas não geram quaisquer efeitos jurídicos válidos, a não ser o direito à percepção dos salários referentes ao período trabalhado e, nos termos do art. 19-A da Lei 8.036/90, ao levantamento dos depósitos efetuados no Fundo de Garantia por Tempo de Serviço - FGTS. 3. Recurso extraordinário desprovido. (BRASIL, 2014) 
Cumpre pontuar que o processo é proveniente de julgamento realizado pela Justiça do Trabalho; contudo, não há como não reconhecer que a essência do debate residiu nos efeitos da decretação de nulidade do contrato celebrado entre o particular e a Administração Pública, sem prévia aprovação em concurso público.

Posteriormente, no julgamento do RE 765.320/MG, o Supremo Tribunal Federal reafirmou o entendimento manifestado no RE 705.140/RS e consignou, nos termos do voto do Ministro Relator, que "é irrelevante a circunstância de o recorrente ter sido submetido ao regime estatutário após sua contratação pelo Estado de Minas Gerais; o que importa é que foi admitido aos quadros do reclamado sem observância dos pressupostos do art. 37, IX, da CF/88" (BRASIL, 2015).

Desse modo, segundo as próprias orientações do STF, não há razão para se afastar o entendimento firmado no RE 705.140/RS, que se aplica indistintamente às contratações realizadas pela Administração Pública em desconformidade com os preceitos do art. 37, IX da Constituição Federal, independentemente de não existir um instrumento formal escrito entre as partes.

No referido julgamento, o STF entendeu que as contratações ilegítimas permitem reconhecer aos contratados o direito à percepção do Fundo de Garantia por Tempo de Serviço (FGTS). Portanto, aos servidores públicos que foram excluídos do Regime Próprio de Previdência a partir da inconstitucionalidade da Lei Complementar n. 100 do Estado de Minas Gerais, deve ser permitida a aplicação da tese firmada no RE 705.140/RS, sendo tal conclusão condizente com a segurança jurídica em relação aos direitos destes trabalhadores, em homenagem, ainda, à uniformização e pacificação da jurisprudência.

Tal conclusão visa permitir, a partir da inconstitucionalidade reconhecida, uma interpretação coerente com os direitos fundamentais constitucionalmente assegurados, considerando, ainda, o papel político contemporâneo do Judiciário, a fim de contribuir para a solução efetiva dos conflitos, assegurando a pacificação social.

\section{CONSIDERAÇÕES FINAIS}

O objetivo geral deste artigo consistiu no exame da Lei Complementar $n^{\circ}$ 100/2007 do Estado de Minas Gerais, reconhecida como inconstitucional pelo Supremo Tribunal Federal no ano de 2014. 
A partir da análise dos motivos que levaram ao surgimento da Lei e dos argumentos apresentados na Ação Direta de Inconstitucionalidade número 4.876, foi possível identificar o problema relativo à modulação dos efeitos da decisão, que buscou defender a segurança jurídica e o excepcional interesse social dos trabalhadores, os chamados "designados", mas acabou representando situação de desigualdade entre aqueles que se encontravam regidos por aquela lei.

Diante deste cenário, surgiram inúmeras ações judiciais com o intuito de ver reconhecidos os direitos sociais destes agentes, excluídos do Regime Próprio de Previdência Social.

Defende-se neste trabalho que, em se considerando o reconhecimento da inconstitucionalidade do artigo $7^{\circ}$ da Lei Complementar $n^{\circ}$ 100/2007, do Estado de Minas Gerais, ou se coloca esses servidores no "limbo jurídico", ou se reconhece que passaram a integrar o regime jurídico administrativo, próprio dos contratados temporariamente, nos termos do artigo 37, IX, da Constituição da República.

Referida conclusão decorre da impossibilidade destes servidores serem considerados efetivos, ou mesmo empregados públicos, regidos pela CLT, ou ainda servidores comissionados, razão pela qual só podem ser enquadrados como servidores públicos temporários, como contemplado no art. 37 , IX, da CR/88, que admite a contratação por tempo determinado para atender à necessidade temporária de excepcional interesse público.

A partir disso, é possível permitir a aplicação da tese apresentada no RE 705.140/RS, que determinou que as contratações ilegítimas não geram quaisquer efeitos jurídicos válidos, a não ser o direito à percepção dos salários referentes ao período trabalhado e, nos termos do art. 19-A da Lei 8.036/90, ao levantamento dos depósitos efetuados no Fundo de Garantia por Tempo de Serviço - FGTS.

Portanto, aos servidores públicos que foram excluídos do Regime Próprio de Previdência a partir da inconstitucionalidade da Lei Complementar n. 100 do Estado de Minas Gerais, deve ser permitida a aplicação da tese firmada no RE 705.140/RS, sendo tal conclusão condizente com a segurança jurídica em relação aos direitos destes trabalhadores, em homenagem, ainda, à uniformização e pacificação social, extremamente importante no cenário atual, mormente em se considerando o papel político contemporâneo do Judiciário.

A sociedade contemporânea vive um cenário de crise diante da incapacidade das instituições públicas em realizar os direitos constitucionalmente assegurados. As 
preocupações acadêmicas, então, devem se voltar a buscar estratégias que transcendam a mera preocupação de estruturação e redução dos processos, a fim de viabilizar instrumentos a permitir solução efetiva dos conflitos, em prol da boa qualidade da prestação jurisdicional.

\section{REFERÊNCIAS}

BRAGA, Luis Felipe Nobre. A técnica da modulação dos efeitos da decisão no controle difuso de constitucionalidade: interpretação extensiva do artigo 27 da lei 9868/99. Artigo. Disponível em: $\quad<$ http://www.ambitojuridico.com.br/site/index.php?n_link=revista_artigos_leitura\&artigo_id $=6577 \% 3 \mathrm{e}>$. Acesso em: 19 de mar. 2017.

BRASIL. Constituição (1988). Constituição brasileira, 1988. Texto constitucional de 05 de outubro de 1988 com as alterações adotadas pelas emendas constitucionais. Brasília: [Senado Federal], 2017. Disponível em: $<$ http://www.planalto.gov.br/ccivil_03/Constituicao/Constituicao.htm>. Acesso em 17. Mar. 2017.

BRASIL. Lei $n^{\circ} 8.745$ de 09 de dezembro de 1993. Dispõe sobre a contratação por tempo determinado para atender a necessidade temporária de excepcional interesse público, nos termos do inciso IX do art. 37 da Constituição Federal, e dá outras providências. Diário Oficial da União, Brasília, 10 dez. 1993b. Disponível em: <http://www.planalto.gov.br/ccivil_03/leis/18745compilada.htm>. Acesso em: 19 mar. 2017.

BRASIL. Lei $\mathrm{n}^{\circ} 9.868$ de 10 de novembro de 1999. Dispõe sobre o processo e julgamento da ação direta de inconstitucionalidade e da ação declaratória de constitucionalidade perante o Supremo Tribunal Federal. Diário Oficial da União, Brasília, 11 nov. 1999. Disponível em: <http://www.planalto.gov.br/ccivil_03/leis/19868.htm>. Acesso em: 19 mar. 2017.

BRASIL. Supremo Tribunal Federal. Ação Direta de Inconstitucionalidade 4.876 DF. Relator: Dias Toffoli. Diário de Justiça Eletrônico, Brasília, 26 mar. 2014. Disponível em: $<$ http://redir.stf.jus.br/paginadorpub/paginador.jsp?docTP=TP\&docID=6272695>. Acesso em: 30 abr. 2017.

BRASIL. Supremo Tribunal Federal. Embargos de Declaração na Ação Direta de Inconstitucionalidade 4.876 ED/DF. Relator: Dias Toffoli. Diário de Justiça Eletrônico, Brasília, 18 ago. 2015.2 Disponível em: <http://www.stf.jus.br/arquivo/cms/noticianoticiastf/anexo/adi4876ed.pdf>. Acesso em: 30 abr. 2017.

BRASIL. Supremo Tribunal Federal. Recurso Extraordinário 705.140/RS. Relator: Teori Zavascki. Diário de Justiça Eletrônico, Brasília, 12 ago. 2015. Disponível em: $<$ http://www.stf.jus.br/portal/processo/verProcessoAndamento.asp?numero=705140\&classe= RE\&origem=AP\&recurso=0\&tipoJulgamento=M>. Acesso em: 30 abr. 2017. 
BRASIL. Supremo Tribunal Federal. Recurso Extraordinário 167.635 RE/DF. Relator: Maurício Correa. Diário de Justiça Eletrônico, Brasília, 07 fev. 1997. Disponível em: $<$ http://redir.stf.jus.br/paginadorpub/paginador.jsp?docTP=AC\&docID=216734>. Acesso em: 30 abr. 2016.

BRÊTAS, Ronaldo de Carvalho Dias. Processo Constitucional e o Estado Democrático de Direito. Belo Horizonte: Del Rey, 2010.

CANOTILHO, José Joaquim Gomes. Direito Constitucional e teoria da constituição. Coimbra, Almedina, 2000.

CARVALHO FILHO, José dos Santos. Manual de direito administrativo. 27. ed. rev. atual. e ampl. São Paulo: Atlas, 2014.

CARVALHO, Kildare Gonçalves. Direito Constitucional. 16. ed. rev. atual. e ampl. Belo Horizonte: Del Rey, 2010. 1616 p.

FERRAZ JR., Tércio Sampaio. Introdução ao estudo do Direito: Técnica, Decisão, Dominação. 2. ed. São Paulo: Atlas, 1994. 368p.

MAGALHÃES, Maria da Conceição Ferreira. A hermenêutica jurídica. Rio de Janeiro: Forense, 1989.

MARTINS, Ives Gandra da Silva. Comentários à Constituição brasileira. São Paulo: Saraiva, 1991. vol. 6 .

MEIRELLES, Hely Lopes. Direito Administrativo Brasileiro. São Paulo: Malheiros Editores, 2001.

MINAS GERAIS. Constituição (1989). Constituição do Estado de Minas Gerais. Belo Horizonte: Assembleia Legislativa do Estado de Minas Gerais, 1997. Disponível em: <http://www.almg.gov.br/opencms/export/sites/default/consulte/legislacao/Downloads/pdfs/C onstituicaoEstadual.pdf>. Acesso em: 02 abr. 2017.

MINAS GERAIS. Decreto $\mathrm{n}^{\circ} 45.155$ de 21 de agosto de 2009. Regulamenta a Lei $\mathrm{n}^{\circ}$ 18.185, de 4 de junho de 2009, que dispõe sobre a contratação por tempo determinado para atender a necessidade temporária de excepcional interesse público, nos termos do inciso ix do art. 37 da Constituição da República. Minas Gerais, Belo Horizonte, 21 de agosto de 2009a. Disponível em: <http://www.almg.gov.br/consulte/legislacao/completa/completa.html?tipo=dec\&num=45 155\&ano=2009>. Acesso em: 19 mar. 2017.

MINAS GERAIS. Lei Complementar $n^{\circ} 100$, de 05 de novembro de 2007. Institui a Unidade de Gestão Previdenciária Integrada - UGEPREVI - Do regime próprio de previdência dos servidores do Estado de Minas Gerais e do regime próprio de previdência social dos militares do Estado de Minas Gerais e o Conselho Estadual de Previdência - CEPREV -, altera a Lei Complementar $n^{\circ}$ 64, de 25 de março de 2002, e dá outras providências. Minas Gerais, Belo Horizonte, 05 nov. 2007.2 Disponível em: 
$<$ http://www.almg.gov.br/consulte/legislacao/completa/completa.html?tipo=lcp\&num=100\&a no=2007>. Acesso em: 05 mar. 2017.

MINAS GERAIS. Lei no 10.254 de 20 de julho de 1990. Institui o regime jurídico único do servidor público civil do estado de minas gerais e dá outras providências. Minas Gerais, Belo Horizonte, 20 de julho de 1990. Disponível em: <http://www.almg.gov.br/consulte/legislacao/completa/completa.html?tipo=lei\&num=10254 $\& a n o=1990>$. Acesso em: 02 abr. 2017.

MINAS GERAIS. Lei n 18.185 de 04 de abril de 2009. Dispõe sobre a contratação por tempo determinado para atender a necessidade temporária de excepcional interesse público, nos termos do inciso ix do art. 37 da Constituição da República. Minas Gerais, Belo Horizonte, 04 de abril de 2009b. Disponível em: <http://www.almg.gov.br/consulte/legislacao/completa/completa.html?num=18185\&ano=200 9\&tipo=lei>. Acesso em: 02 abr. 2017.

MOTTA, Fabrício. Direitos fundamentais e concurso público. Revista do tribunal de contas do Estado de Minas Gerais. esp. ed. ano XXVIII. Disponível em: <http://revista.tce.mg.gov.br/content/upload/materia/926.pdf>. Acesso em 16 abr. 2016.

SANTORO, José Jayme de Souza. Manual de direito previdenciário. 2. ed. Rio de Janeiro: Freitas Bastos Editora, 2001. Disponível em: $<$ https://www.ensinonacional.com.br/to/curso/direitoprevidenciario/manualdedireitoprevidenci\%c3\%a1riop2.pdf $>$. Acesso em 16 abr. 2017.

SILVA, José Afonso da. Curso de Direito Constitucional Positivo. $28^{a}$ edição - São Paulo, Malheiros, 2006.

TASSINARI, Clarissa. Jurisdição e ativismo judicial: limites da atuação do judiciário. Porto Alegre: Livraria do Advogado Editora, 2013. 